\title{
In vitro propagation of rare species Rhodiola rosea from Altai Mountains
}

\author{
A. A. $\operatorname{Erst}^{1 *}$, A. S. Erst $^{1,2}$, A. I. Shmakov ${ }^{3}$ \\ ${ }^{1}$ Central Siberian Botanical Garden, Russian Academy of Sciences, Zolotodolinskaya st., 101, Novosibirsk, 630090, \\ Russian Federation.E-mail: annaerst@yandex.ru \\ ${ }^{2}$ Tomsk State University, 36 Lenin Ave., Tomsk, 634050, Russian Federation.E-mail: erst_andrew@yahoo.com \\ ${ }^{3}$ South-Siberian Botanical Garden, Altai State University, Lenina pr. 61, Barnaul, 656049, \\ Russian Federation.E-mail: bot@asu.ru \\ *Corresponding author.E-mail: annaerst@yandex.ru
}

Keywords: ex vitro acclimatization, in vitro propagation, planting material, Rhodiola rosea.

Summary. The techniques of biotechnology are considered promising and highly-demanded for propagation and conservation of rare species of medicinal plants. The variety of natural forms of Rhodiola rosea makes it difficult to develop a single efficient in vitro protocol for this valuable and rare medicinal plant. The optimization of in vitro methods for specific populations to effectively mass production of planting material $R$. rosea is required. The paper provides the technique for in vitro propagation of $R$. rosea from the population of Altai Mountains, including sterilization of seeds in an aqueous solution of sodium hypochlorite, planting of seedlings on Murashige and Skoog medium (MS) supplemented with $5 \mu \mathrm{M}$ 6-benzylaminopurine (BAP) and $2.5 \mu \mathrm{M} \alpha$-naphthylacetic acid (NAA), rooting of microshoots on hormone-free $1 / 2$ MS medium and acclimatization in the substrate consisting of peat and perlite at a ratio of $2: 1$. We have shown that no additional pre-sowing treatment is required for effective in vitro germination of $R$. rosea seeds. The seedlings of $R$. rosea exhibit a high germination rate and are a promising explant type for in vitro mass propagation of the plant. This technique provides a high yield of in vitro cultivated plants ( 6.3 plants per explant, $95-100 \%$ rooting) and a high percentage of plant acclimatization (78 \%). The average weight of roots (wet weight) during acclimatization and growth (7 months) was $12.2 \pm 2.4 \mathrm{~g}$. The developed technique of in vitro propagation of $R$. rosea allows both to conserve the natural populations of this rare plant and to obtain planting material for commercial cultivation.

\section{Размножение в культуре in vitro редкого вида Rhodiola rosea с Алтая}

\author{
А. А. Эрст ${ }^{1 *}$, А. С. Эрст ${ }^{1,2}$, А. И. Шмаков ${ }^{3}$ \\ ${ }^{1}$ Центральный Сибирский ботанический сад СО РАН, ул. Золотодолинская, 101, г. Новосибирск, 630090, Россия \\ ${ }^{2}$ Томский государственный университет, пр. Ленина, 36, г. Томск, 634050, Россия \\ ${ }^{3}$ Южно-Сибирский ботанический сад, Алтайский государственный университет, \\ пр. Ленина, 61, г. Барнаул, 656049, Россия
}

Ключевые слова: адаптация к условиям ex vitro, размножение in vitro, посадочный материал, Rhodiola rosea.

Аннотация. В настоящее время применение методов биотехнологии для размножения и сохранения редких видов лекарственных растений является перспективным и востребованным направлением. Разнообразие природных форм Rhodiola rosea (родиолы розовой) затрудняет разработку единого эффективного протокола размножения in vitro этого ценного и редкого лекарственного растения. Для эффективного использования 
технологий in vitro с целью массового размножения родиолы розовой требуется оптимизация методик для конкретных популяций. В результате работы предложен способ размножения in vitro R. rosea из популяции Горного Алтая, включающий стерилизацию семян в водном растворе гипохлорита натрия, высаживание проростков на питательную среду Мурасиге и Скуга (MS), дополненную $5 \mu \mathrm{M}$ 6-бензиламинопурина (БАП) и 2,5 $\mu \mathrm{M} \alpha$-нафтилуксусной кислоты (НУК), укоренение микропобегов на безгормональной среде $1 / 2 \mathrm{MS}$ и адаптацию в субстрате состоящем из торфа и перлита в соотношении $2: 1$. Нами показано, что в культуре in vitro для эффективного прорастания семян родиолы розовой не требуется дополнительная предпосевная обработка. А проростки родиолы розовой характеризуются быстрыми темпами роста и являются перспективным типом экспланта для массового размножения этого растения в культуре in vitro. Данная технология обеспечивает высокий выход растений-регенерантов в культуре in vitro (6,3 растений на эксплант; 95-100 \% укоренение) и 78\%-ю адаптацию растений к условиям ex vitro. Средняя масса корней (сырой вес) за период адаптации и доращивания (7 месяцев) составила 12,2 $\pm 2,4$ г. Размножение в культуре in vitro родиолы розовой позволяет, как сохранять природные популяции этого редкого растения, так и получать посадочный материал для коммерческого выращивания.

\section{Introduction}

Rhodiola rosea L. (golden root) from the family Crossulariaceae is a medicinal plant with a wide range of secondary metabolites, the most important of which are salidroside and alcohol derivatives of cinnamic acid and glycosides (phenylpropanoids) rosavine, rosin and rosarin (which are referred to as rosavins) accumulated in the plant rhizome. There are about 58 species of the genus Rhodiola (Ohba, 2005), but rosavins are found only in $R$. rosea. This species is of great value both in traditional medicine and in natural food industry due to its unique composition (Kurkin, Zapesochnaya, 1986; Saratikov, Krasnov, 2004; Panossian et al., 2010; Stepanova et al., 2016). Nevertheless, global commercial demand for $R$. rosea is almost exclusively satisfied by wild harvested plants. $R$. rosea is very popular among the local people, which leads to uncontrolled harvesting of this plant and, hence, to depletion of natural wild populations. Currently, $R$. rosea is listed as endangered species and included in the Red Data Book of the Russian Federation (Nekratova, 2008). The species is recommended for inclusion in the IUCN Red List of Threatened Species.

Thus, the conservation of the genetic diversity of natural populations of $R$. rosea and provision of the pharmaceutical industry with this kind of plant material is possible only through commercial cultivation (Galambosi, 2005). It is known that $R$. rosea can be vegetatively propagated through cuttings of the underground part of the plant. However, this process is very laborious and slow to be used in large-scale commercial cultivation. The main problems of cultivation of plants from seeds are low germination rate and mass death of seedlings in the open ground, which requires greenhouses to grow immature plants. This process takes two years, after which the plants can be transplanted to the open ground. A very promising technique for mass production of the planting material is to employ clonal micropropagation.

The first studies on the in vitro cultivation of R. rosea were carried out 30 years ago (Kaftanat et al., 1988). A number of papers are devoted to the study of the micropropagation characteristics of this species. They consider the issues related to the effect of the medium composition and of various types of explants on the organogenesis and regeneration of $R$. rosea cultivated in vitro and identification of factors inducing these processes (Furmanowa, 1995; Ishmuratova, 1998; Yin et al., 2004; Tasheva, Kosturkova, 2010; Bae et al., 2012). A significant number of studies reported on the cell culture and genetically transformed roots of $R$. rosea as producers of biologically active substances, and on the techniques to enhance their biosynthesis (Furmanova et al., 2002; György, 2006; Krajewska-Patan et al., 2007; Grech-Baran et al., 2015; Marchev et al., 2016; Lütken et al., 2017). However, only a few papers address the production of the planting material for commercial cultivation (Platikanov, Evstatieva, 2008; Rhodiola rosea..., $2015)$. Considering that the species $R$. rosea is characterized by a high intraspecific morphological and biochemical variability, it is necessary to optimize the in vitro method for specific populations of this species (Ishmuratova, 1998; Kim, 1999; Zakhozhyy, 2006; Poletaeva et al., 2013).

The paper aims to develop the biotechnology technique for obtaining $R$. rosea planting material. The resulting method has the potential to be used for reintroducing $R$. rosea to mountain areas and for commercial cultivation of this species.

\section{Materials and methods}

Rhodiola rosea $\mathrm{L}$. is a rare, arctic-alpine species with an almost circumpolar distribution. This 
herbaceous perennial is widespread at high altitudes in the arctic and mountainous regions of Europe, Asia and North America (Nekratova, 2008). The most promising plants for introduction into culture with respect to the content of secondary metabolites, in particular salidroside, are $R$. rosea plants from the Republic of Altai. Introductory experiments performed earlier showed the ability of $R$. rosea to accumulate salidroside (up to $1.6 \%$ ) and to exhibit high biological productivity, which makes it a good candidate for cultivation in different soil climatic zones, in various altitude belts and on the plain (Poletaeva et al., 2013).

The object of the study was $R$. rosea plants from the Republic of Altai growing on the southern slopes of the Iolgo range, Karakol lakes, 1800-2000 m a. s. 1.

Rhodiola rosea was cultivated in vitro at the Biotechnology Laboratory, Central Siberian Botanical Garden SB RAS (Novosibirsk). Sterilization was fulfilled in a laminar flow hood (Lamsystems, Russia). $R$. rosea seeds were the material for in vitro cultivation, development and optimization of the micropropagation technology. Surface sterilization was performed in accordance with the following scheme: seeds were immersed in $70 \%$ ethanol for 30 seconds and then in $20 \%$ Domestos (sodium hypochlorite) solution for 20 minutes (orbital shaker, $100 \mathrm{rpm}$ ) followed by threetime washing with sterile distilled water. For in vitro seed germination, a $0.6 \%$ aqueous solution of agar (Difco, USA) was used.

Most of the studies on $R$. rosea have shown that Murashige and Skoog medium (MS) (Murashige, Skoog, 1962) was most optimal for propagation of this species, and therefore it was taken as a basic medium. During shoot multiplication, the medium was supplemented with $10 \mu \mathrm{M}$ BAP (6-benzylaminopurine), zeatin and TDZ (thidiazuron) at a concentration of $1: 5$, and with $5 \mu \mathrm{M}$ BAP in combination with $2.5 \mu \mathrm{M}$ NAA ( $\alpha$-naphthylacetic acid). For rooting, half-strength MS medium ( $1 / 2 \mathrm{MS})$ supplemented with $5 \mu \mathrm{M}$ IBA (indole-3-butyric acid) was used. The source of carbohydrates was sucrose (30 g/l), and the medium $\mathrm{pH}$ was adjusted to 5.8 before autoclaving. The passage lasted 30-35 days.

The conditions of explant cultivation were as follows: photoperiod - 16/8-hour light/dark cycle, illumination intensity $-2-3 \mathrm{klx}$, and temperature $24 \pm 1{ }^{\circ} \mathrm{C}$. Seeds were germinated in the light and in the dark.

To conduct the in vitro study of the morphogenesis, the following parameters were considered: propagation coefficient as the number of developed shoots in one explant (pieces/explant), rooting ( $\%)$, and the number of roots per explant (pieces/explant).

The in vitro cultivated plants were acclimatized to non-sterile conditions in cassettes, the substrate consisted of perlite and peat $(1: 2)$. The substrate was wetted with fungicide solution (Bactofit, Russia), at a concentration of $10 \mathrm{~g}$ per 5 liters of water or a weak solution of potassium permanganate to prevent and control fungal and bacterial plant diseases. Within the first five days, the plants were covered with a transparent film to provide high humidity for acclimatization. The plants were grown indoors at $24 \pm 2{ }^{\circ} \mathrm{C}$, illumination intensity of $2-3 \mathrm{klx}$ within a photoperiod of 16/8-hour light/dark cycle for 30 days. After a month, the plants were transplanted into $10 \times 10 \times 11 \mathrm{~cm}$ containers by transferring to a soil mixture that consisted of peat and sand at a ratio of $2: 1$ and were grown for 7 months under greenhouse conditions.

Statistical processing of the results and analysis of the obtained data were carried out using Microsoft Excel 7.0. All the experiments were performed in 2 replicates of 20-30 plants in each replication. The data are presented as mean values and confidence intervals $(\mathrm{p} \leq 0.05)$

$\mathrm{X} \pm \mathrm{t} \times \mathrm{S}_{\mathrm{x}}$, where $\mathrm{X}$ is sample mean $\mathrm{t}$ is Student's test,

$\mathrm{S}_{\mathrm{x}}$ is sampling error.

\section{Results and Discussion}

Significant progress has been made in the field of biotechnology of medicinal plants - cultivation of cells, tissues and organs of Panax ginseng, Catharanthus roseus, Dioscorea deltoidea and species of the genus Digitalis, Arnica montana, Rauwolfia and Galanthus (Ramachandra, Ravishankar, 2002; Verpoorte et al., 2002; Khan, 2009). A number of papers address the micropropagation of $R$. rosea (Furmanowa, 1995; Ishmuratova, 1998; Yin et al., 2004; Tasheva, Kosturkova, 2010; Bae et al., 2012), however, the results of these studies are contradictory due to large polymorphism of this species and the presence of numerous ecotypes.

\section{In vitro cultivation}

We have shown that $R$. rosea seeds germinate after 2-3 days of cultivation in both light and dark cycles (Fig. 1). The seed germination of the Mountain Altai population was $31 \%$ for the 3rd day and $52 \%$ for the 6th day of cultivation. After a month of growing 
R. rosea on $0.6 \%$ agar, 3-4 shoots developed, and the shoot base thickened (Fig. 1c).

According to the literature data, $R$. rosea seeds exhibit variable morphological features, heterogeneous quality, low germination rate (7$24 \%$ ) and energy (up to $2 \%$ ) (Kim, 1999).

The choice of the explant tissue for in vitro introduction is crucial for successful realization of the morphogenetic potential of plant cells. Various types of explants were used for $R$. rosea propagation: leaves and leaf disks, axillary buds, shoot segments, and renewal buds of the rhizome (Dimitrov et al., 2003, Yin et al., 2004; Tasheva, Kosturkova, 2010). Apical buds of in vitro seedlings of $R$. rosea were also studied (Kirichenko et al., 1994). The possibility of in vitro propagation was shown for other representatives of the genus Rhodiola $R$. crenulata, $R$. yunnanensis, $R$. fastigata and $R$. sachalinesis - using different types of explants
(Hai-jun et al., 2006). Shoot segments were the most efficient explant type for $R$. crenulata, the leaf explant showed the best results for the other three species.

We have shown no additional pre-sowing treatment is required for effective in vitro germination of $R$. rosea seeds. The seedlings of $R$. rosea exhibit a high germination rate and are a promising explant type for in vitro mass propagation of the plant.

\section{In vitro propagation}

At the stage of micropropagation, the medium was supplemented with cytokinins, alone or in combination with auxins, to remove apical dominance and to produce the largest number of shoots. We studied the effect of cytokinins BAP, zeatina, TDZ and auxin NAA on shoot production of $R$. rosea (Table).

Table

Effect of plant growth regulators on in vitro shoot production of Rhodiola rosea

\begin{tabular}{|c|c|c|}
\hline & Plant growth regulators, $\mu \mathrm{M}$ & Number of shoots/explants \\
\hline & Control & 1 \\
\hline \multirow{3}{*}{ BAP } & 1 & $1.9 \pm 0.6$ \\
\hline & 5 & $4.6 \pm 1.2$ \\
\hline & 10 & $6.2 \pm 1.5$ \\
\hline \multirow{3}{*}{ TDZ } & 1 & $2.3 \pm 0.8$ \\
\hline & 5 & $6.2 \pm 1.3$ \\
\hline & 10 & $3.5 \pm 0.9$ \\
\hline \multirow{3}{*}{ Zeatin } & 1 & $2.2 \pm 1.0$ \\
\hline & 5 & $4.1 \pm 0.8$ \\
\hline & 10 & $6.5 \pm 1.4$ \\
\hline & $\operatorname{BAP}(5)+$ NAA $(2.5)$ & $6.3 \pm 1.1$ \\
\hline
\end{tabular}

The studies showed that a high concentration of cytokinins BAP or zeatin $(10 \mu \mathrm{M})$ promoted $R$. rosea shoot formation, however, a negative process of shoot hyperhydratation was observed. Addition of $5 \mu \mathrm{M}$ TDZ to culture medium triggered $R$. rosea budding but caused the formation of shortened shoots. Addition of $5 \mu \mathrm{M}$ BAP and $2.5 \mu \mathrm{M}$ NAA to culture medium resulted in an increased propagation coefficient of $R$. rosea $(6.3 \pm 1.1)$ compared to the control and in formation of shoots of standard morphology (Fig. 2).

The plant genotype and the combination and concentration of growth regulators in the medium are important for in vitro regeneration in various representatives of the genus Rhodiola. Thus, differences in ecotypes appeared to be an important factor influencing the processes of efficient callogenesis and organogenesis of $R$. rosea and
$R$. iremelica (Ishmuratova, 1998). The optimal concentration of the cytokinin BAP for the Altai $R$. rosea were 10-15-fold higher for induction of in vitro cultures from immature leaves explants from a Tibetan golden root (Yin et al., 2004). The combination of $2.5 \mathrm{mg} / 1 \mathrm{BAP}$ and $0.1 \mathrm{mg} / 1 \mathrm{NAA}$ was found to be optimal for $R$. crenulata and $R$. yunnanensis and enhanced shoot formation by 71 and $84 \%$. The medium containing higher concentrations of auxin NAA $(0.5 \mathrm{mg} / \mathrm{l})$ at a similar BAP concentration was more appropriate for propagation of $R$. fastigata and $R$. sachalinesis, and the regeneration was $80 \%$ (Hai-jun et al., 2006).

The mineral composition of the medium and the combination and concentration of growth regulators significantly affect callus formation, organogenesis, and regeneration. Various compositions of culture media - Murashige and Skoog (MS), Linsmaer and 
Skoog, Gamborg, White, Nitsch and Nitsch - have been previously tested for $R$. rosea. The medium is typically supplemented with various combinations and concentrations of growth regulators. The most commonly used regulators for cultivation of $R$. rosea are BAP, $\alpha$-indoleacetic acid (IAA), NAA, IBA, and 2.4-dichlorophenoxyacetic acid (2.4-D). The effect of zeatin, 2-izopentiladenin (2-iP), kinetin and TDZ was studied as well (Tasheva, Kosturkova, 2012).

\section{In vitro rooting}

The success of in vitro technologies depends to a large extent on the stage of microshoot rooting. Regeneration of roots in different varieties and species differs and depends on both the plant ability to perceive rooting factors and the rooting methods used. Efficient rooting on the medium containing IBA was observed for $R$. fastigata and R. sachalinesis ( $87 \%$ and $73 \%$, respectively). The auxin at a concentration of $2 \mathrm{mg} / \mathrm{l}$ was found to be efficient for R. rosea (Tasheva, Kosturkova, 2010).

At the stage of rhizogenesis, we observed 95$100 \%$ rooting for microshoots of the selected forms of $R$. rosea on both hormone-free $1 / 2$ MS medium and media supplemented with IBA (Fig. 2b). The average number of roots was $6.5 \pm 1.9$ per plant.

\section{Ex vitro acclimatization}

Various substrates are used for acclimatization of the representatives of the genus Rhodiola. For example, a substrate containing soil, peat, and sand at a ratio of $3: 1: 1$ ensured acclimatization of $70 \%$
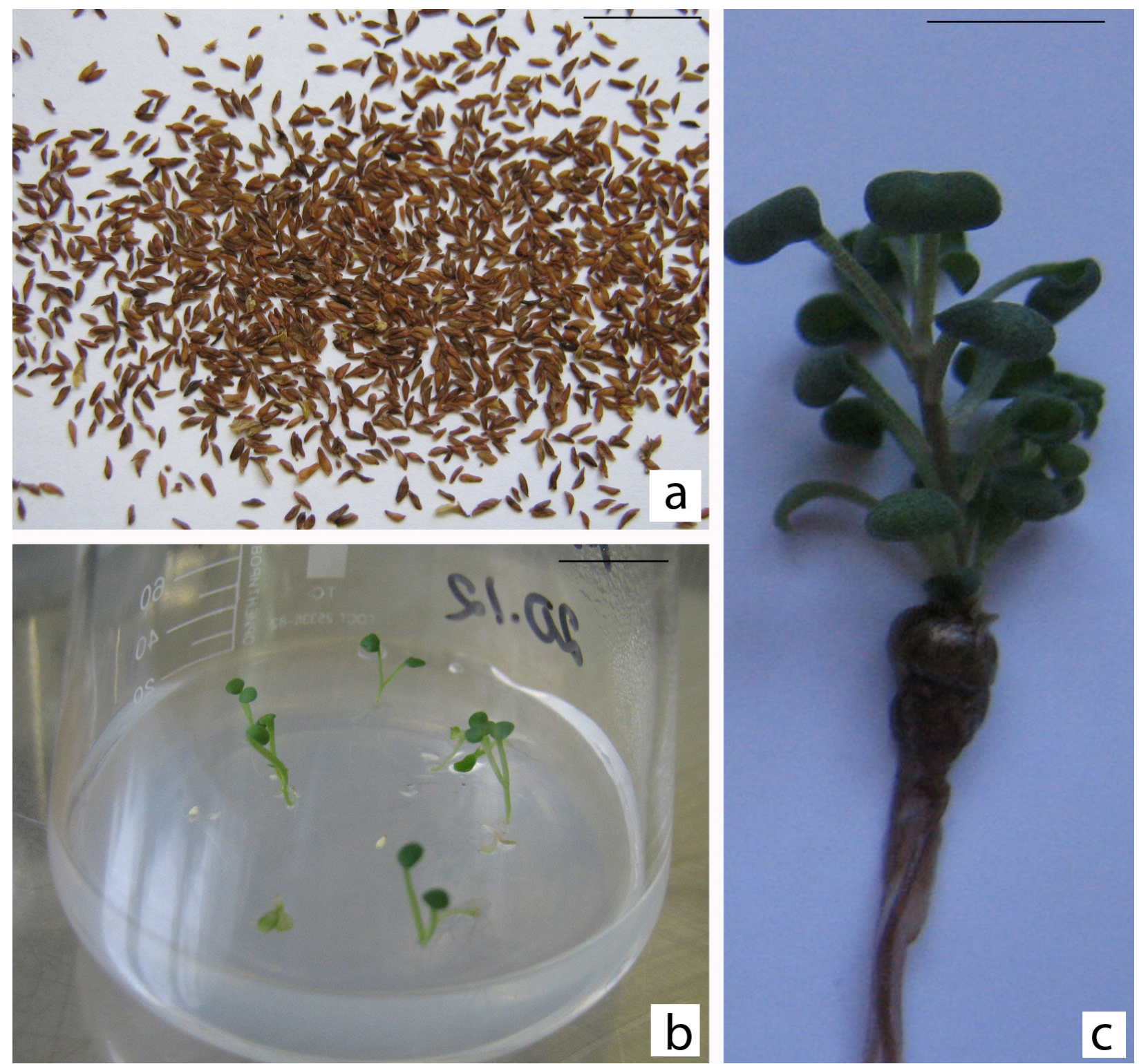

Fig. 1. Rhodiola rosea: $\mathrm{a}$ - seeds; $\mathrm{b}$ - seedlings on $0.6 \%$ agar after 10 days of cultivation; $\mathrm{c}$ - seedlings on $0.6 \%$ agar after 30 days of cultivation. Bar: $1 \mathrm{~cm}$. 


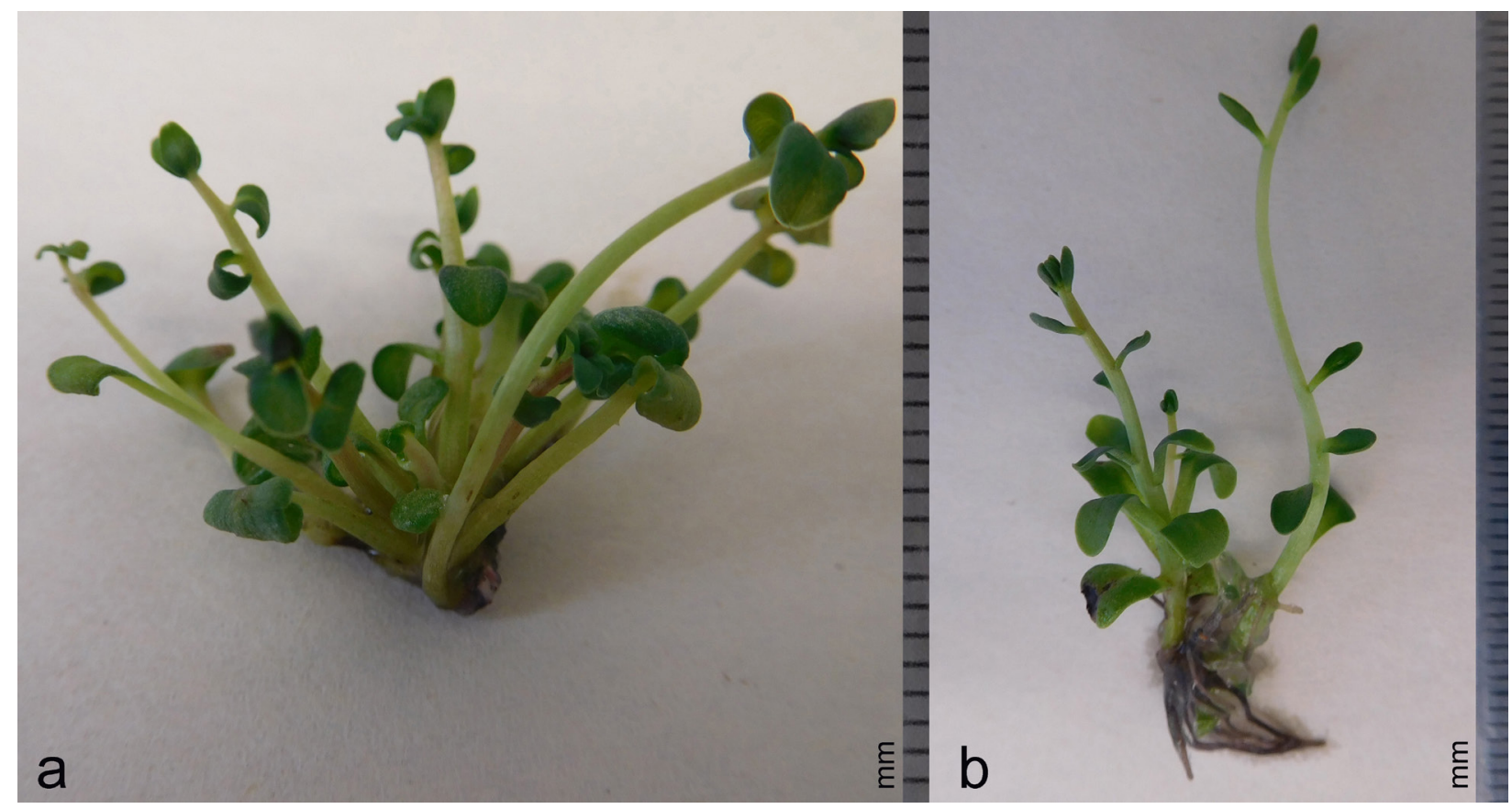

Fig. 2. In vitro cultivation of Rhodiola rosea: a - on MS medium supplemented with $5 \mu \mathrm{M}$ BAP and $2.5 \mu \mathrm{M}$ NAA; $\mathrm{b}-$ on $1 / 2$ MS medium.

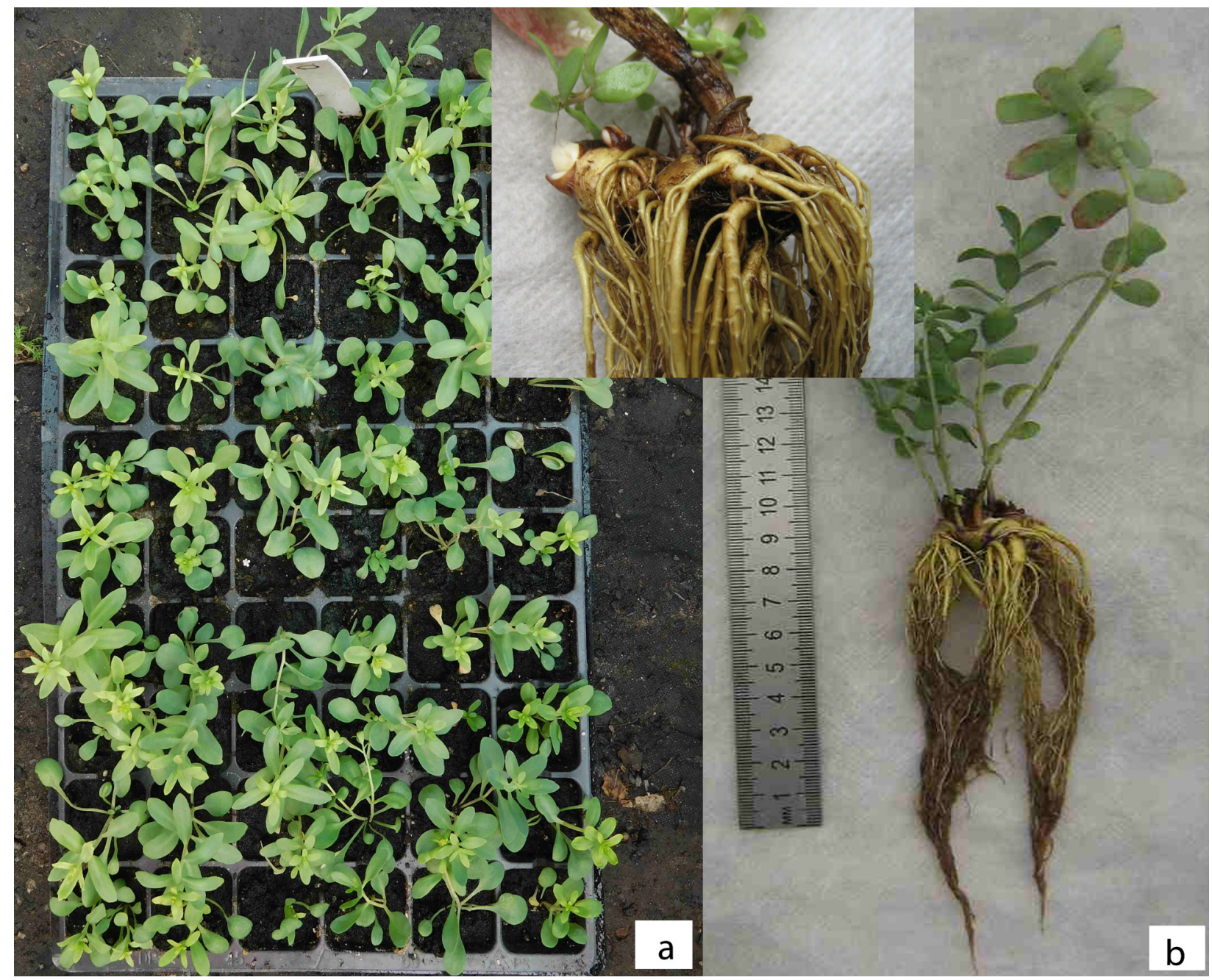

Fig. 3. Acclimatized plants of Rhodiola rosea: a - after 1 month of cultivation in cassettes; $\mathrm{b}$ - root system washed from the substrate and part of the rhizome with renewal buds. 
of $R$. rosea plants and $66 \%$ of $R$. fastigata plants (Hai-jun et al., 2006).

Acclimatization of $R$. rosea plants was carried out in the substrate consisting of perlite and peat at a ratio of $1: 2$ that ensured $78-84 \%$ acclimatization (Fig. 3). In this substrate, the root system was observed to develop well, and the subsequent transplantation was carried out without disturbing the roots.

The average weight of roots (wet weight) during acclimatization and growth (7 months) was $12.2 \pm$ $2.4 \mathrm{~g}$. According to the literature data, the mass of $R$. rosea roots under natural conditions was $0.12-0.42$ $1.66 \mathrm{~g}$ in one-two-three-year plants, respectively. The root mass in cultivated plants (propagation by seeds) was $1.19-11.01-52.41 \mathrm{~g}$, respectively. It was noted that $R$. rosea plants retain characteristics typical of natural populations when transferred and grown in culture medium. The ontogenetic development rate in cultivated plants was higher than that in plants growing under natural conditions. Cultivated plants exhibited an increased size of the aboveground and underground parts, accelerated growth of underground parts and their changed structure. Cultivated plants significantly exceeded wild-growing individuals in biomass; the share of caudex and roots was about $80 \%$ of the plant weight (Platikanov, Evstatieva, 2008; Rhodiola rosea..., 2015).

We have shown that in vitro cultivation of $R$. rosea plants accelerates plant development. Seven-month-old plants of $R$. rosea cultivated in accordance with the biotechnology technique elaborated in the present study correspond to twoyear-old plants grown by traditional reproduction techniques from seeds with respect to the parameters of the development of the aboveground part and biomass of the rhizome with roots.

Efficiency of the developed technique was as follows: seed germination $-52 \%$, sterility of explants $-100 \%$, propagation coefficient at the stage of shoot multiplication -6.3 pieces per explant, the number of rooted microshoots $-95 \%$, the number of roots per plant $-6.5 \pm 1.9$ pieces per explant, and the number of acclimatized plants $-78 \%$.
The amount of the planting material that can be obtained based on the quantitative characteristics of the developed protocol for $R$. rosea plant propagation was calculated by the formula:

$$
\mathrm{N} \times \mathrm{M}^{\mathrm{y}} \times 0.95
$$

where $\mathrm{N}$ is the number of initial explants, $\mathrm{M}$ is the propagation coefficient, $\mathrm{y}$ is the number of subcultivations, and 0.95 is the rooting coefficient.

The calculations showed that one plant can produce 400000 in vitro grown plants a year. Taking into account the percentage of plant acclimatization to ex vitro conditions $(78 \%)$ and the time required for completing of the growth cycle, 312000 seedlings can be obtained from one plant within 2 years.

\section{Conclusion}

$R$. rosea or golden root is a valuable medicinal plant, the populations of which are significantly reduced due to uncontrolled harvesting. Biotechnology techniques, in particular, clonal micropropagation, enable in vitro propagation of the plant material and make the basis for the development of industrial plantations for ex situ conservation of $R$. rosea. The developed technique of clonal micropropagation and its optimization make it possible to obtain the planting material of high quality. Taking into account propagation coefficients, more than 300000 plants of $R$. rosea can be cultivated within a year. The plants cultivated in vitro exceed those grown by traditional methods in growth parameters, which helps to reduce the cycle of seedlings production from two to one year.

Acknowledgements. The work was carried out within the framework of the State Assignment to Central Siberian Botanical Garden, SB RAS AAAA-A17-117012610051-5 "Assessment of morphogenetic potential of North Asian plant populations by experimental methods" (No. 0312-20160001).

In our study in vitro material from collection No. USU_440534 "Collection of living plants indoors and outdoors" was used.

\section{REFERENCES / ЛИTЕРАTУРA}

Bae K-H, Ko M. S., Kim N. Y., Song J. M., Song G. P. 2012. In vitro propagation and multiple shoot induction of Rhodiola rosea L. by axillary bud culture. J. Plant Biotechnol. 39: 114-120. DOI: 10.5010/JPB.2012.39.2.114

Dimitrov B., Tasheva K., Zagorska N., Evstatieva L. 2003. In vitro cultivation of Rhodiola rosea L. Genetics and Breeding 32(1-2): 3-6.

Furmanova M., Hartwich M., Alferman A. W. 2002. Glucosylation of p-tyrosol to salidroside by Rhodiola rosea L. cell cultures. Herba Pol. 48: 71-76. 
Furmanova M., Oledzka H., Michalska M., Sokolnicka I., Radomska D. 1995. XXII. Rhodiola rosea L. (Roseroot): in vitro Regeneration and the Biological Activity of Roots. In: Biotechnology in Agriculture and Forestry, Medicinal and Aromatic Plants. VIII. Ed. Y. P. S. Bajaj. Springer, Heidelberg 33: 412-426.

Galambosi B. 2005. Rhodiola rosea L. from wild collection to field production. Medicinal Plant Conservation 11(1): 31-35.

Grech-Baran M., Syklowska-Baranek K., Pietrosiuk A. 2015. Biotechnological approaches to enhance salidroside, rosin and its derivatives production in selected Rhodiola spp. in vitro cultures. Phytochem. Rev. 14: 657-674.

György Z. 2006. Glycoside production by in vitro Rhodiola rosea cultures. Ph. D Thesis, University of Oulu, Oulu, Finland.

Hai-jun L., Bin G., Qiong Y., Yu-jun L., Chun-Zhao L. 2006. Tissue culture of four Rhodiola species. Acta Botanica Boreali-Occidentalia Sinica 26(10): 2023-2027.

Ishmuratova M. M. 1998. Clonal micropropagation of Rhodiola rosea L. and R. iremelica Boriss. in vitro. Rastitelnyye resursy [Plant Resources] 34: 12-23 [In Russian]. (Иимуратова М. М. Клональное микроразмножение Rhodiola rosea L. и R. iremelica Boriss. in vitro // Растительные ресурсы, 1998. T. 34. С. 12-34).

Kaftanat V. N., Bodrug M. V., Floryia $\boldsymbol{V}$. N. 1988. Enhanced multiplication of Rhodioloa rosea in Moldova. In: Proceedings of the Second National Conference on Medicinal Botany. Kiev, USSR, 64 p.

Khan M. Y., Aliabbas S., Kumar V., Rajkumar S. 2009. Resent Advances in Medcinal Plant Biotehology. Indian Journal of Biotechnology 8: 9-22.

Kim E. F. 1999. Rodiola rozovaya (zolotoy koren) sem. Tolstyankovykh i biologicheskiye osnovy vvedeniya eye $v$ kulturu [Rhodiola rosea (golden root) of the family Crassulaceae and biological basis of its introduction into the culture cultivation: abstract of the thesis of doctor of biological sciences]. Novosibirsk, 20 pp. [In Russian]. (Kum $\boldsymbol{E}$. $\boldsymbol{\Phi}$. Родиола розовая (золотой корень) сем. Толстянковых и биологические основы введения ее в культуру: автореф. ... Д-ра биол. наук. Новосибирск, 1999. 20 с.).

Kirichenko E. B., Rudenko S. S., Baglaj B. M., Masikevich U. G. 1994. Leaf culture from in vitro propagated Rhodiola rosea. Bulletin GBS, RAN 169: 50-54.

Krajewska-Patan A., Dreger M.., Lowicka A.., Gorska-Paukszta M.., Mścisz A.., Mielcarek S., et al. 2007. Chemical investigation of biotransformed Rhodiola rosea callus tissue. Herba Pol. 53: 77-87.

Kurkin V. A., Zapesochnaya G. G. 1986. Chemical composition and pharmacological properties of plants of the genus Rhodiola plants (review). Khimiko-farmatsevticheskiy zhurnal [Pharmaceutical Chemistry Journal] 20(10): 1231-1244 [In Russian]. (Куркин В. А., Запесочная $\boldsymbol{\Gamma}$. Г. Химический состав и фармакологические свойства растений рода родиола (обзор) // Хим.-фармац. журн., 1986. Т. 20, № 10. С. 1231-1244).

Lütken H., Meropi-Antypa N., Kemp O., Hegelund J. N., Müller R. 2017. Hairy root cultures of Rhodiola rosea to increase valuable bioactive compounds. In: Production of plant derived natural compounds through hairy root culture. Ed. S. Malik. Springer, Cham, 89-116 pp. DOI: https://doi.org/10.1007/978-3-319-69769-7_4

Marchev A. S., Dinkova-Kostova A. T., György Z. 2016. Rhodiola rosea L.: from golden root to green cell factories. Phytochem. Rev. 15: 515-536. DOI: 10.1007/s11101-016-9453-5

Murashige T., Skoog F. 1962. A revised medium for rapid growth and bioassays with tobacco tissue cultures. Physiol. plant 15(13): 473-497.

Nekratova N. A. Rhodiola rosea L. 2008. In: Red Data Book of the Russian Federation (plants and fungi). Eds. R. V. Kamelin, V. S. Novikov. Partnership of scientific publications KMK, Moscow, 855 pp. [In Russian]. (Некратовa H. A. Rhodiola rosea L. // Красная книга Российской Федерации (растения и грибы). М.: Товарищество научных изданий КМК, 2008. 855 с.).

Ohba H. 2005. Rhodiola. Illustrated handbook of succulent plants: Crassulaceae. Berlin, 210-227 pp.

Panossian A. Wikmana G. Sarris J. 2010. Rosenroot (Rhodiola rosea): Traditional use, chemical composition, pharmacology and clinical efficacy. Phytomedicine 17: 481-493. DOI: 10.1016/j.phymed.2010.02.002

Platikanov S., Evstatieva L. 2008. Introduction of wild golden root (Rhodiola rosea L.) as a potential economic crop in Bulgaria. Econ Bot. 62(4):621-627.

Poletaeva I. I., Volodina S. O., Volodin V. V. 2013. Studying the individual variability of Rhodiola rosea L. plants for selection the valuable genotypes for microclonal reproduction. Izvestia of RAS Samara Scientific Center 15(3): 769-775 [In Russian]. (Полетаева И. И., Володина С. О., Володин В. В. Изучение индивидуальной изменчивости растений Rhodiola rosea L. в целях отбора ценных генотипов для микроклонального размножения // Известия Самарского научного центра Российской академии наук. 2013. Т. 15, № 3(2). С. 769-775).

Ramachandra Rao S., Ravishankar G. A. 2002. Plant cell cultures: chemical factories of secondary metabolites. Biotechnology Advances 20(2): 101-153.

Rhodiola rosea. Traditional herbal medicines for modern times. 2015. Eds. Alain Cuerrier, Kwesi Ampong-Nyarko, CRC Press, 282 pp.

Saratikov A. S., Krasnov E. A. 2004. Rodiola rozovaya (zolotoy koren) [Rhodiola rosea (golden root)]. Tomsк, 292 pp. [In Russian]. (Саратиков $\boldsymbol{A}$. С., Краснов Е. А. Родиола розовая (золотой корень). Томск, 2004.292 с.). 
Stepanova E. F., Shirzad B., Evseeva S. B. 2016. Rhodiola rosea: the state of the studies and the possibilities of creating cosmeceutical and dermatological medicinal product. Pharmacia and pharmacology 4 (5): 36-62 [In Russian]. (Степанова Э. Ф., Ширзад Б., Евсеева С. Б. Родиола розовая: состояние исследований и возможности создания космецевтических и дерматологических средств // Фармация и фармакология, 2016. Т. 4, № 5. С. 36-62). DOI: 10.19163/2307-9266-2016-4-5-36-62

Tasheva K., Kosturkova G. 2010. Bulgarian golden root in vitro cultures for micropropagation and reintroduction. Central European Journal of Biology 5(6): 853-863.

Tasheva K., Kosturkova G. 2012. The role of biotechnology for conservation and biologically active substances production of Rhodiola rosea: Endangered Medicinal Species. The Scientific World Journal ID 274942. DOI: $10.1100 / 2012 / 274942$

Verpoorte R., Contin A., Memelink J. 2002. Biotechnology for the production of plant secondary metabolites. Phytochemistry Reviews 1(1): 13-25. DOI: 10.1023/A:1015871916833

Yin W. B., Li W., Du G. S., Huang Q. N. 2004. Studies on tissue culture of Tibetan Rhodiola rosea. Acta Bot. Boreal. Occident. Sin. 24: 1506-1510.

Zakhozhyy I. G. 2006. Fiziologo-biokhimicheskiye osnovy nakopleniya produktov vtorichnogo metabolizma-salidrozida i rozavina $v$ rasteniyakh Rhodiola rosea L. [Physiological and biochemical basis of accumulation of products of secondary metabolism - salidroside and rosavin in plants of Rhodiola rosea L.: abstract of the thesis of candidate of biological sciences]. St. Petersburg, 19 pp. [In Russian]. (Захожий И. Г. Физиолого-биохимические основы накопления продуктов вторичного метаболизма - салидрозида и розавина в растениях Rhodiola rosea L. Автореф. ... канд. биол. наук. СПб., 2006. 19 с.). 